\title{
A Study on Conversion of Marine Diesel Engines Using Blended Palm Oil for Inland Waterway Vessels in Vietnam
}

\author{
Dang Van Uy \\ Marine Engineering Department, VMU (Vietnam Maritime University), Hai Phong City 180000, Vietnam
}

\begin{abstract}
The climate change and limitation of natural resources becomes main obstacle for the global economical development. So, the Vietnamese Government is very much concerned with reduction of harmful gas discharging from the inland-water way ships. To overcome the problems, there are many counter-measures proposed such as: renovation of machinery and equipment, using re-creative energy and so on. The author's idea is to find a suitable method which can be applied on board of the inland-water ships to reduce discharging toxic gas by using blended palm oil as alternative fuel for marine diesel engines. Due to some disadvantages of the bended palm oil in comparison with traditional DO (diesel oil), such as: low freezing point, high viscosity, low stability of blended fue, therefore somehow, the blended palm oil must be made a ship directly on board. With this idea, the author has designed and made agitate mixing equipment working on-line with fuel supply system of a diesel engine. The mixing equipment, then, has been tested at shore-side laboratory as well as on board ships. The research results showed that the fuel mixture (palm oil-DO) made by this mixing equipment is fully usable to replace traditional DO for marine diesel engines installed on board ships of inland water way in Vietnam. The Vietnamese Government accepted the research results as prerequisite to devise specific and practical action plans to reduce the pollution from the inland water way ships in coming years.
\end{abstract}

Key words: Blended palm oil, pure palm oil, Vietnam inland waterway vessels, VMU, renovation.

\section{Introduction}

Environmental protection and using fuel efficiency are the top priorities to be solved in many countries in the world including Vietnam. Vietnam's economy is not big, but it consumes about 13 million tons of liquid fuels in 2010 and this consumption is expected to reach 37 million tons in 2020, of which the means of water transport account for over $30 \%$.

IMO (International Maritime Organization) has confirmed that the water transport vehicles carry over $80 \%$ of global commodity and have made significant contribution to environmental pollution by emitting toxic gases such as $\mathrm{CO}_{x}, \mathrm{NO}_{x}$ and $\mathrm{SO}_{x}$. In Vietnam, the number of waterway transport means is about 176,636 units and they emit about 30 million tons of

Corresponding author: Dang Van Uy, Ph.D., research fields: maritime engineering sciences and ship's technology. E-mail: dvuy@hn.vnn.vn. toxic gases annually. In order to reduce the amount of harmful emissions into the environment, there are several measures: applying modern techniques to improve diesel engines quality, using fossil fuels with low content of sulfur, using bio-fuels.

In Vietnam, thousands of inland waterway ships and fishing vessels with main engines with capacity from several tens to thousands horsepower have consumed considerable amounts of fuel DO (diesel oil) and emitted millions of tons of harmful gases, thus it is necessary to have solutions to limit environmental pollutants as request mentioned in Annex VI of MARPOL 73/78 of International Convention. To solve problem of air pollution caused by emissions from the ships, the bio-fuels (renewable fuel) are to be investigated as alternative fuel for marine diesel engines and among those bio-fuels, the pure palm oil is selected. The research results will be a prerequisite 
for the Vietnamese Government to devise specific and practical action plans to meet the requirements of MARPOL 73/78 International Convention and contribute to the overall protection of the environment.

\section{Specific Features of Diesel Propulsion System of Inland Waterway Fleet}

Vietnam has a network of rivers and canals which are very convenient for water transport, especially in the area of the Red River Delta and the Mekong River Delta. The fleet of inland waterway transport in Vietnam includes the vessels with capacity from several hundred to over 3,000 DWT and their propulsion system consists of a diesel engine (main engine) driving a propeller and 1 to 2 diesel generators. The structure and number of water transport vessels in Vietnam are shown in table 1.

The marine propulsion plant and fuel supply system of inland transport fleet are relatively simple. The propulsion plant includes a diesel indirectly driving propeller through the gearbox and clutch. The main diesel engines are usually from Daihatsu, Hanshin, Yanmar (Japan), Weichai (China) and the engines are manufactured in the Republic of the Russian Federation. The main diesel engines and diesel generators are using DO or heavy diesel oil (Marine diesel oil-MDO). The structure of propulsion system of inland waterway vessels is outlined in Fig. 1.

The fuel supply system of inland waterway vessels is one of the most important systems related to the research process, therefore, it will be carefully analyzed in this section. The structure of the fuel supply system is shown in Fig. 2.

The main functions of this system are [1-3]:
- storing and maintaining fuel for the ships;

- processing fuel to achieve the quality standards before entering the engines;

- supplying fuel to each cylinder of a diesel engine at right time and right amount in accordance with external load of an engine;

- collecting excess fuel after each operating cycle of the high pressure pumps and bringing it back to the fuel oil tank.

Thus, with the function as described above, the fuel supply system serves as "hardware" and fuel is like "software" in the process of using fuel for the diesel engines. So when changing fuel by other one, it is necessary to study carefully the technical characteristics of the current fuel supply system and make decisions about the changes to the system to suit the new type of fuel.

\section{Features of Palm Oil and Its Influences on the Operation of Diesel Engines}

Palm tree is a type of monocotyledons plant, belonging to the Elaeis group. Palm tree gives high oil capacity and the annual average reaches 3.7 tons per hectare. Palm tree is mostly planted in some countries such as Malaysia, Indonesia and Thailand. One of the most important steps to generate biodiesel fuel is through transesterification process that transforms triglyceride molecule into smaller molecule with straight structure relatively similar to that of fossil diesel fuel. The application of sophisticated technology and equipment in the transesterification process makes the price of bio-diesel higher, whereas if the pure palm oil could be used, the price would be cheaper and it creates opportunities for alternative fuel. That is also the purpose of our research.

Table 1 The total number of ship of Vietnam.

\begin{tabular}{lllll}
\hline No. & Fleets & Number of ship & Deadweight (millions DWT) & Power (millions HP) \\
\hline 1 & Oceangoing ship & 1,636 & 7.1 & 4.5 \\
2 & Inland ship & 90,000 & 4.0 & 3.5 \\
3 & Fishing ship & 83,000 & - & 4.0 \\
\hline
\end{tabular}

Source: Vietnam Maritime Administration, World Bank. 


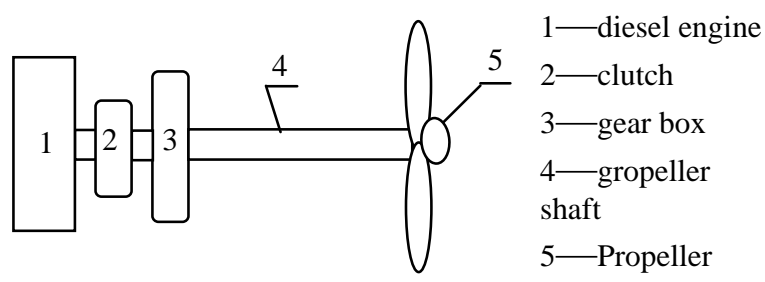

Fig. 1 Basic components of propulsion plant.

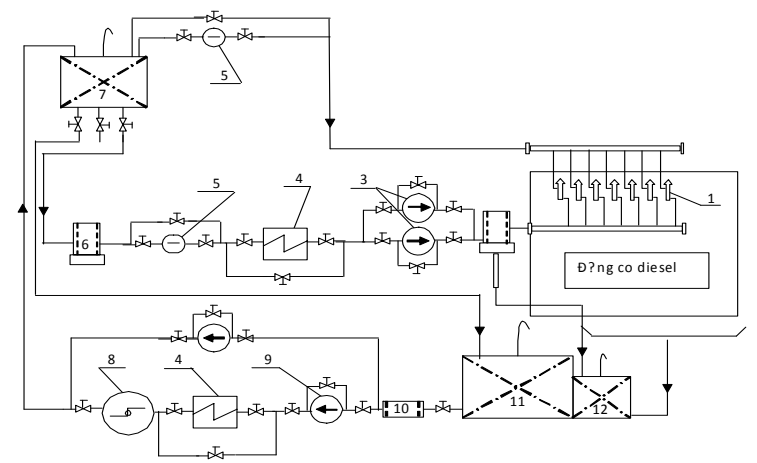

1-high pressure pump; 2-fine filter (duplex); 3-fuel oil pump; 4-heater; 5-flow meter; 6-primary filter (duplex); 7-service tank; 8-purifier; 9-transfer pump; 10-filter; 11-DO storage tank; 12 -sludge tank.

Fig. 2 Fuel supply system for marine diesel engine.

\subsection{Analysis and Evaluation of Physio-chemical Properties of Palm Oil}

To get in-depth knowledge of palm oil, it is necessary to understand about the structure of its molecule. First and foremost, palm oil is formed by triglyceride with three elements: carbon, hydro and oxygen. The world-wide researches show that in the molecules of palm oil, there are $5 \%$ of fatty acid, it is a kind of acid facilitating the hydrolysis process (replace alcohol by water); $0.25 \%$ of water under lactic-acid and sediment-that is contaminated source of fuel; changing color of the oil phenomenon reached 2.31 basis — an indicator of oxidation capacity [3, 4].
In the components of palm oil, there are nine types of fatty acids that are classified by the number of the carbon atom contained in each molecule. There are two kinds of fatty acids: saturated acid and unsaturated acid, in which saturated acids exist more stable than unsaturated acids. The saturated and unsaturated character of fatty acids have affected to the physical feature of palm oil as it is used as fuel for a diesel engine.

It is better to distinguish the definition of oil and fat in palm oil. Many people assume that oil and fat share the similar features, but in fact, there are differences between them: in the temperature of $20{ }^{\circ} \mathrm{C}$, oil is in liquid state while fat is in solid state, and oil normally comprises of majority of unsaturated fatty acids.

Table 2 provides the differences between palm oil and traditional diesel oil that is widely used for diesel engines of Vietnamese inland waterway fleet. To evaluate the possibility of using the pure palm oil for marine diesel engines, it is necessary to analyze its physio-chemical features in comparison with diesel oil once. These physio-chemical features include kinematic viscosity, calorific value, flash point and Cetan number.

Analysis of physio-chemical features showed that the kinematic viscosity of palm oil is 14 times higher than that of diesel oil at temperature of $15{ }^{\circ} \mathrm{C}$, calorific value of palm oil is $10 \%$ smaller than that of DO, flash point of palm oil is threefold that of DO and freezing point of DO is significantly lower than that of palm oil, and Cetan number of palm oil is $15 \%$ greater than that of DO. Therefore, to replace the diesel oil by palm oil using for diesel engines must encounter below obstacles:

Table 2 Physio-chemical features of palm oil and diesel oil.

\begin{tabular}{|c|c|c|c|c|c|c|c|c|c|c|}
\hline Feature & $\begin{array}{l}\text { Density } \\
\text { in } 15{ }^{\circ} \mathrm{C} \\
\left(\mathrm{kg} / \mathrm{m}^{3}\right)\end{array}$ & $\begin{array}{l}\text { Kinematic } \\
\text { viscosity } \\
\text { At } 40^{\circ} \mathrm{C}, \mathrm{mm}^{2} / \mathrm{s}\end{array}$ & $\begin{array}{l}\text { Cetan } \\
\text { value }\end{array}$ & $\begin{array}{l}\text { Fash } \\
\text { point }\left({ }^{\circ} \mathrm{C}\right)\end{array}$ & $\begin{array}{l}\text { Freezing } \\
\text { point }\left({ }^{\circ} \mathrm{C}\right)\end{array}$ & $\begin{array}{l}\text { Ash } \\
\text { content, } \\
\text { \% mass }\end{array}$ & $\begin{array}{l}\text { Copper } \\
\text { corrosion at } \\
50{ }^{\circ} \mathrm{C} \text { within } \\
3 \text { hours. }\end{array}$ & $\begin{array}{l}\text { Water } \\
\text { content } \\
(\mathrm{mg} / \mathrm{kg})\end{array}$ & $\begin{array}{l}\text { Acid value, } \\
\text { (mg } \\
\mathrm{KOH} / \mathrm{g})\end{array}$ & $\begin{array}{l}\text { Calorific } \\
\text { value, } \\
\text { kcal/kg }\end{array}$ \\
\hline Palm oil & 0.9225 & 85.80 & 42.89 & 224 & 16 & 0.0061 & $1 \mathrm{~A}$ & 315 & 0.4 & 10,325 \\
\hline $\begin{array}{l}\text { Diesel } \\
\text { oil }\end{array}$ & 0.8464 & 6.38 & 52.92 & 72 & -6 & 0.0054 & $1 \mathrm{~A}$ & 170 & 0.35 & 10,750 \\
\hline
\end{tabular}


- Engine capacity will be substantially reduced;

- It is required to heat fuel to a high temperature to reach the adequate viscosity for diesel engines. This may lead to coking phenomenon of fuel that is dangerous for engine fuel supply system and engine itself;

- It could potentially cause slow burning in the combustion chamber of diesel engines due to high flash point and low Cetan number of palm oil;

- There are some difficulties due to heat required during transportation and storage of palm oil.

In short, the replacement of palm oil for diesel oil as an alternative fuel for marine diesel engines may create harmful effects on the engines. Therefore, in order to effectively use palm oil to replace diesel oil, it is essential to have suitable technological solution with acceptable cost.

\subsection{Evaluating Applicability of Pure Palm Oil and} Blended Palm Oil as Alternative Fuel for Marine Diesel Engines by the Simulation

In order to estimate the applicability of pure palm oil and blend palm oil to substitute DO, the simulation method has been applied to investigate the combustion of pure palm oil and its mixture in the combustion chamber of a diesel engine then to compare with that when using DO for the same engine. The mathematical models simulating combustion process have been built based on the first thermodynamic law that is known as the law of energy balance for a thermodynamic system.

The diesel engines are considered a closed heating system and in the case of very small changes of crankshaft rotation, the equation of energy conservation under the thermodynamics law I can be written as follows $[5,6]$ :

$$
\mathrm{d} U=\partial Q-\partial W
$$

In which: $\partial Q$-heat release of the fuel oil $\left[\mathrm{kJ} /{ }^{\circ}\right.$ Crankshaft Angle]; $\partial W=P d V$ — work raise; $\mathrm{d} u=m C_{v} \mathrm{~d} T$-rate of change in energy.

By the transformations, it is could be built as the mathematical models to calculate the pressure of combustion process, the heat release and combustion temperature in the combustion chamber and the model assessing of delay combustion has also built as follows $[1,7,8]$ :

The combustion pressure:

$$
\frac{\mathrm{d} P}{\mathrm{~d} \theta}=\frac{k-1}{V}\left[Q_{i n} \frac{\mathrm{d} f}{\mathrm{~d} \theta}-\frac{h A}{\omega}\left(T_{g}-T_{w}\right) \frac{\pi}{180}\right]-k \frac{P}{V} \frac{\mathrm{d} V}{\mathrm{~d} \theta}
$$

The heat release:

$$
\frac{\mathrm{d} Q_{n e t}}{\mathrm{~d} \theta}=\frac{C}{r}\left(P \frac{\mathrm{d} V}{\mathrm{~d} \theta}+V \frac{\mathrm{d} P}{\mathrm{~d} \theta}-\frac{P V}{m} \frac{\mathrm{d} m}{\mathrm{~d} \theta}\right)+P \frac{\mathrm{d} V}{\mathrm{~d} \theta}
$$

And formula for calculating heat loss and heat transfer by thermal convection:

$$
\frac{\mathrm{d} Q_{\text {loss }}}{\mathrm{d} \theta}=A\left(a_{c} \frac{K}{B} R_{e}^{b}\left(T_{g}-T_{w}\right)+c_{r}\left(T_{g}^{4}-T_{w}^{4}\right)\right)
$$

Besides, the above formulas, the heat release that calculated with heat loss, will also be determined:

$$
\frac{\mathrm{d} Q_{\text {gross }}}{\mathrm{d} \theta}=\frac{\mathrm{d} Q_{\text {net }}}{\mathrm{d} \theta}-\frac{\mathrm{d} Q_{\text {loss }}}{\mathrm{d} \theta}
$$

The combustion temperature:

$$
\frac{\mathrm{d} T}{\mathrm{~d} \theta}=\frac{1}{m C_{v}} Q_{i n} \frac{\mathrm{d} f}{\mathrm{~d} \theta}-\frac{h A\left(T_{g}-T_{w}\right)}{m C_{v}}-\frac{R T}{C_{v} V} \frac{\mathrm{d} V}{\mathrm{~d} \theta}
$$

Determining the delay combustion:

It is enough to use Hardenberg and Hase [7] formula evaluating the fuel combustion delay:

$$
\tau_{i d}(G Q T K)=\left(0.36+0.22 \bar{S}_{p} \exp \left[E_{A}\left(\frac{1}{\overline{\mathrm{R}} T_{c y l}}-\frac{1}{17.190}\right)\left(\frac{21.1}{P_{c y l}-12.4}\right)^{0.63}\right]\right.
$$

Based on Eqs. (1)-(7) and applying MATLAB software [9], it is quite good to simulate the combustion process in the combustion chamber for any type of diesel engines and fuels. Then simulations have been carrying out to evaluate combustion of diesel fuel, pure palm oil and blended palm oil (called PO) at concentrations from 5\% to 30\% (PO5 to PO30) in specific marine diesel engine. For purpose of the research, the physical and chemical properties of pure palm oil, DO and blended palm oil are also created as shown in Table 3.

The diesel engine which is used in simulation, is 6LU32 HANSHIN (Japan). The engine is often used as a main engine on the inland waterway vessels 
Table 3 The characteristics of investigating fuels.

\begin{tabular}{lllllllllll}
\hline $\begin{array}{l}\text { Fuel } \\
\text { properties }\end{array}$ & $\begin{array}{l}\text { Density at } \\
15{ }^{\circ} \mathrm{C} \\
\left(\mathrm{kg} / \mathrm{m}^{3}\right)\end{array}$ & $\begin{array}{l}\text { viscosity } \\
40 \\
\mathrm{~mm}^{2} / \mathrm{s}\end{array}$ & $\begin{array}{l}{ }^{\circ} \mathrm{C} \text {, number } \\
\text { alm }\end{array}$ & $\begin{array}{l}\text { Flash } \\
\text { point } \\
\left({ }^{\circ} \mathrm{C}\right)\end{array}$ & $\begin{array}{l}\text { Freezing } \\
\text { point }\left({ }^{\circ} \mathrm{C}\right)\end{array}$ & $\begin{array}{l}\text { Ash } \\
\text { content, } \\
(\%) \\
\text { weight }\end{array}$ & $\begin{array}{l}\text { Copper } \\
\text { corrosion } \\
\text { at } 50{ }^{\circ} \mathrm{C} \text { in 3 } \\
\text { hours }\end{array}$ & $\begin{array}{l}\text { Water } \\
\text { content } \\
(\mathrm{mg} / \mathrm{kg})\end{array}$ & $\begin{array}{l}\text { Acid } \\
(\mathrm{mg} \mathrm{KOH} / \mathrm{g})\end{array}$ & $\begin{array}{l}\text { number, Heat, } \\
\mathrm{kcal} / \mathrm{kg}\end{array}$ \\
\hline Palm oil & 0.9225 & 85.80 & 42.89 & 224 & 16 & 0.0061 & $1 \mathrm{~A}$ & 315 & 0.4 & 10,325 \\
DO & 0.8464 & 6.38 & 52.92 & 72 & -6 & 0.0054 & $1 \mathrm{~A}$ & 170 & 0.35 & 10,750 \\
PO5 & 0.8489 & 7.0 & 52.11 & 72 & -3 & 0.0057 & $1 \mathrm{~A}$ & 182 & 0.36 & 10,700 \\
PO10 & 0.8538 & 7.42 & 51.25 & 73 & -1 & 0.0057 & $1 \mathrm{~A}$ & 189 & 0.37 & 10,625 \\
PO15 & 0.8568 & 8.20 & 50.91 & 74 & 0 & 0.0057 & $1 \mathrm{~A}$ & 195 & 0.37 & 10,620 \\
PO20 & 0.8599 & 9.31 & 50.66 & 75 & 1 & 0.0058 & $1 \mathrm{~A}$ & 201 & 0.38 & 10,580 \\
PO25 & 0.8632 & 9.87 & 50.13 & 76 & 2 & 0.0058 & $1 \mathrm{~A}$ & 208 & 0.38 & 10,475 \\
PO30 & 0.8668 & 10.45 & 49.63 & 77 & 2 & 0.0058 & $1 \mathrm{~A}$ & 215 & 0.40 & 10,350 \\
\hline
\end{tabular}
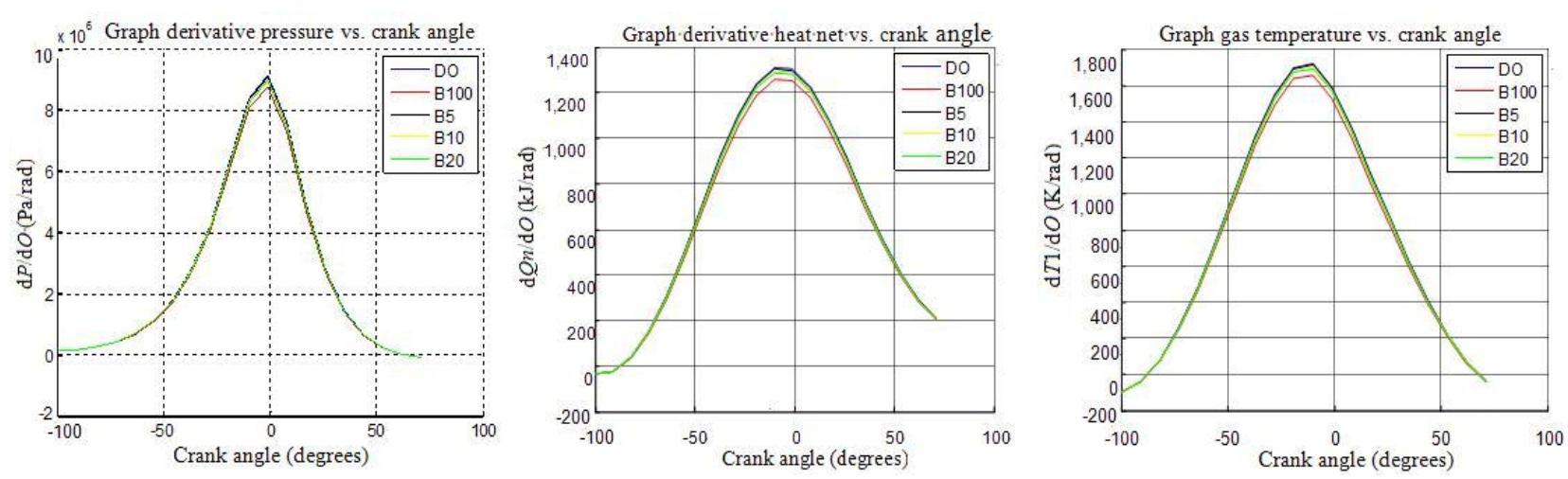

Fig. 3 Change features of pressure, temperature and heat release at fuel mode $100 \%$ of engine $6 \mathrm{LU} 32$.

in Vietnam. It is 4 strokes engine type with nominal power of $900 \mathrm{~kW}$, engine revolution $340 \mathrm{r} / \mathrm{min}$; cylinder diameter $320 \mathrm{~mm}$, piston stroke $520 \mathrm{~mm}$; fuel consumption rate of $200 \mathrm{~g} / \mathrm{kW} \cdot \mathrm{h}$. Simulation results are shown in Fig. 3 and the results of the analysis as shown in Tables 4 and 5.

Based on the simulation results of combustion process of different fuels used for 6LU32 diesel engine, a number of remarks can be made:

The combustion process inside the cylinders of diesel engine 6LU32 using palm oil resembles the one in the same engine when using DO. The biggest difference can be mentioned as the engines use palm oil: maximum combustion pressure decreased by $6.66 \%$; the maximum temperature dropped nearly $4 \%$, emission declined by $7.4 \%$ as well; while, as the engine used PO5, PO10, PO20, PO30 (mixture fuel), maximum combustion pressure, maximum temperature and emission decreased in range from $1 \%$ to $3 \%$;
Using palm oil and its mixture fuel, the diesel engine produced smaller capacity in comparison with using DO; lower calorific of bio-diesel is the reason why the difference is made; however, this difference is not significant;

It seems that: the lower the engine load is, the less difference between the operation parameters when using the palm oil or its mixture fuel and the DO fuel is. At $100 \%$ load mode, the reduction of the maximum combustion pressure between DO and B100 fuel is $6.66 \%$, while at $85 \%$ load mode, it is $4.39 \%$ and at $75 \%$ load mode, it is only $4.08 \%$.

\section{Proposed Conversion of Marine Diesel Engines to Use Blended Palm Oil as Fuel for Inland Waterway Vessels}

Based on the above analyses of the characteristics of palm oil, blended palm oil and the simulation results using palm oil and its mixture as an alternative fuel, there are some remarks: 
Table 4 The difference of parameters depending on the type of fuels.

\begin{tabular}{|c|c|c|c|c|c|c|c|}
\hline \multirow{3}{*}{$\frac{\text { No. }}{1}$} & \multirow{3}{*}{$\begin{array}{l}\text { Type of fuels } \\
\text { DO }\end{array}$} & \multicolumn{6}{|c|}{ Change features } \\
\hline & & \multicolumn{2}{|c|}{ Pressure $\left(\mathrm{kG} / \mathrm{cm}^{2}\right)$} & \multicolumn{2}{|c|}{ Temperature $\left({ }^{\circ} \mathrm{C}\right)$} & \multicolumn{2}{|c|}{ Heat release $(\mathrm{kJ} / \mathrm{rad})$} \\
\hline & & 90 & - & 1719 & - & 1,350 & - \\
\hline 2 & $5 \% \mathrm{PO}$ & 89 & $-1.11 \%$ & 1712 & $-0.40 \%$ & 1,330 & $-1.48 \%$ \\
\hline 3 & $10 \% \mathrm{PO}$ & 88 & $2.22 \%$ & 1706 & $-0.76 \%$ & 1,310 & $-2.96 \%$ \\
\hline 4 & $20 \% \mathrm{PO}$ & 87 & $-3.33 \%$ & 1696 & $-1.35 \%$ & 1,300 & $-3.70 \%$ \\
\hline 6 & $30 \% \mathrm{PO}$ & 86.5 & $3.80 \%$ & 1690 & $-1.68 \%$ & 1,290 & $-4.44 \%$ \\
\hline 5 & Palm oil & 84 & $-6.66 \%$ & 1651 & $-3.95 \%$ & 1,250 & $-7.40 \%$ \\
\hline
\end{tabular}

Table 5 Combustion delay of various fuels.

\begin{tabular}{lllllllll}
\hline & \multicolumn{7}{c}{ Type of fuel oil } \\
\cline { 2 - 8 } & B100 & DO & B5 & B10 & B15 & B20 & B25 & B30 \\
\hline $\begin{array}{l}\text { Delay of combustion } \\
\begin{array}{l}\text { ( Crankshaft Angle) before } \\
\text { TDC (Top Dead Center) }\end{array}\end{array}$ & 2.3003 & 2.1978 & 2.2049 & 2.2127 & 2.2158 & 2.2181 & 2.2231 & 2.2279 \\
\hline $\begin{array}{l}\text { Increasing ( }{ }^{\circ} \text { Crankshaft } \\
\begin{array}{l}\text { Angle) and (\%) in comparison } \\
\text { with DO }\end{array}\end{array}$ & $\begin{array}{l}0.101 \\
4.595\end{array}$ & - & 0.007 & 0.0140 & 0.018 & 0.020 & 0.025 & 0.030 \\
\end{tabular}

The use of pure palm oil as an alternative fuel is not feasible, the main reason is that palm oil has a lots of fat so when burned, it would create a lots of smoke; moreover, pure palm oil has a very high spontaneous combustion temperature and low calorific value, it will make many negative effects on working cycles of diesel engines;

As a result, it is suitable to use the blended palm oil. The blended PO will be made by mixing pure palm oil with DO with different percentage amount of pure palm oil. The blended palm oil has physio-chemical features very similar to that of DO, however, the diesel engine may reduce significantly toxic emission in exhaust gas as using the blended palm oil.

\subsection{The Required Criteria of Conversion and the Proposed Conversion}

Based on the analyses of the supply fuel system mentioned in Section 2 as well as the operation technical conditions of the Vietnam's inland waterway fleets, there are some required criteria to convert the diesel engines of inland waterway vessels in order to use the blended palm oil for the main engines:

- The basic functions of the fuel supply system outlined in Section 2 are preserved;
- It is not necessary to change the basic elements of the old fuel system such as high-pressure pumps, nozzles, camshaft;

- Economic relations of ship-owners to the initial investment and long-term economic efficiency must be taken into account;

- The required technical conditions prescribed by the Classification Association and SOLAS 74 are fulfilled [3].

\subsection{Converting the Fuel Supply System for Using} Mixed Fuel

The investigation results showed that the mixed fuel types from PO5 to PO30 have similar properties with DO fuel, especially from PO5 to PO15 (Table 3); the maximum combustion pressure, heat release and temperature of combustion are relatively equivalent to DO usage; from PO5 to PO15, the ignition delay is very similar to DO (slower $0.3 \div 0.8 \%$ than $\mathrm{DO}$ ).

So, the purpose of research is only to carry out modification of the fuel supply system in simplest way in order to achieve the highest efficiency of diesel engines when using the blended palm oil and the core idea is to create a mixture fuel matching technical requirement of the diesel engines. To make a suitable 
fuel mixture for the diesel engines is not simple, since the mixed fuel is easily separated at low temperatures, failed to make the necessary uniformity, and difficulties in storage. To solve these problems, the continuous mixing system (on-line) was proposed, both mixing and supplying amount of fuel are equal. Then, the agitator type mixer was selected due to its advantages in comparison with other ones [15]. After designing, manufacturing and testing many times, the suitable size, mixing temperature and speed of stirring of mixer were found. Fig. 4 shows the reformed fuel supply system for blended palm oil fuel; Fig. 5 illustrates the structure diagram of continuous mixing system, and the fuel real mixer installed on the fuel supply system is shown in Fig. 6.

\subsection{Experiment Results of the Blended Fuel Usage}

In order to evaluate the possibility of using blended palm oil made by the continuous mixing system, several tests were performed in laboratory and on board ships.

The test was carried out in Ship Propulsion System Laboratory of VMU. The testing system includes: HANSHIN engine 6LU32 (Japan); the measurement equipment such as AVL and Kistler combustion pressure indicators; photographic combustion equipment from AVL (Austria). Besides these, there are other devices such as thermometers, manometers, stopwatch, measuring fuel consumption equipment, fuel heaters data. In Fig. 7, the engine and measuring equipment in the laboratory.

On the Tables 7-9, there are measured data when the engine 6LU32 operating with different load modes and types of the blended fuels. The concerning parameters in the testing process: fuel consumption, combustion delay and $\mathrm{NO}_{\mathrm{x}}$ concentration in the exhaust gas of the engine.

Based on actual data taken during test carried out at the laboratory, some conclusions were made as follows:

The fuel consumption rate of $\mathrm{DO}, \mathrm{PO} 5$ and $\mathrm{PO} 10$ are quite similar due to the quite low part of palm oil in the blended fuel, then the lower calorific value of the blended fuel is quite similar to DO; the fuel consumption of PO20 higher than other fuels.

Taking the moment of ignition of DO as a standard time to verify the start of combustion of the other

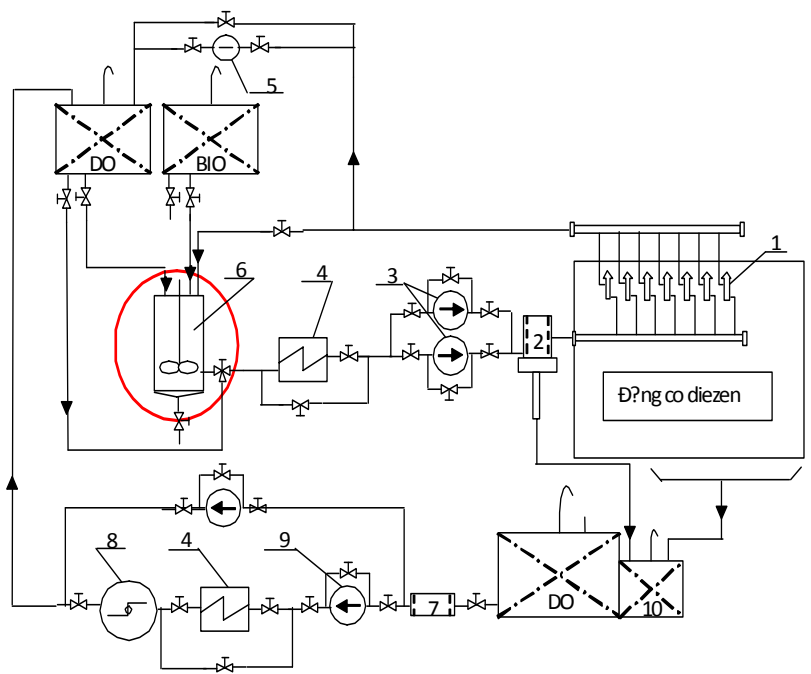

1-high pressure pump; 2-fine filter (duplex); 3-supply pump; 4-heater; 5-flow meter; 6-mixing equipment; 7-primary filter; 8-purifier; 9-transfer pump; 10—sludge tank.

Fig. 4 Fuel supply system with palm oil mixer onboard ship.

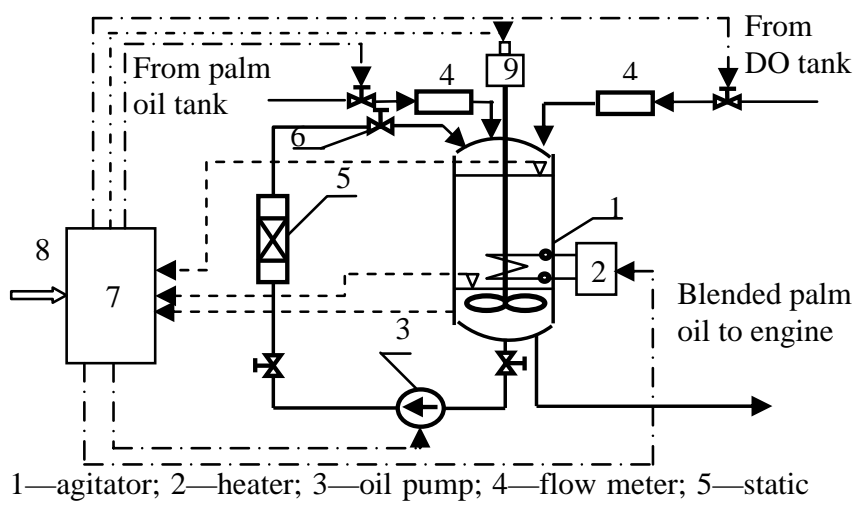
mixing tube; 6-valve; 7—control panel.

Fig. 5 Structure of fuel mixing system.

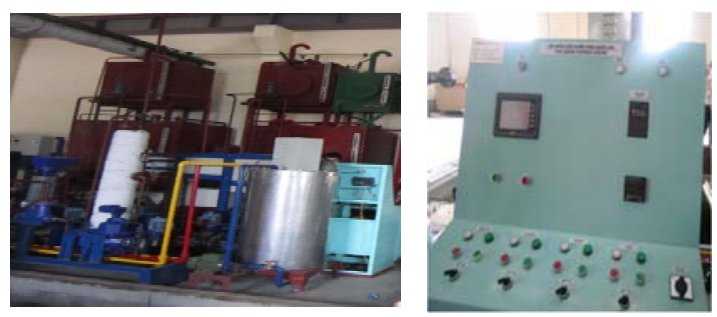

Fig. 6 Real on-line fuel mixing system. 

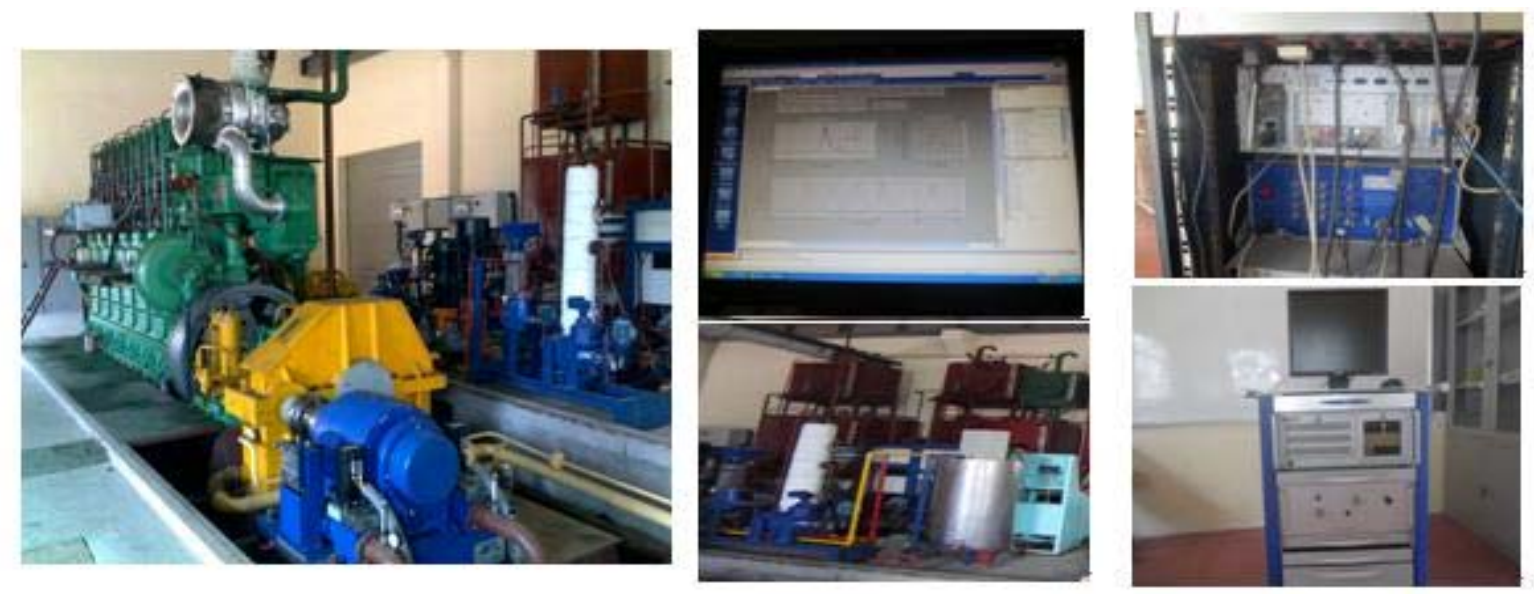

Fig. 7 Diesel engine, palm oil mixer and measurement equipment.

Table 7 Fuel consumption for different blending fuel.

\begin{tabular}{lllllll}
\hline Operating regime & & \multicolumn{5}{c}{ Fuel consumption (g/kW.h) } \\
\hline Load (kW) & Revolution (rpm) & DO & PO5 & PO10 & PO15 & PO20 \\
200 & 188 & 280 & 287 & 290 & 290 & 295 \\
400 & 238 & 259 & 269 & 269 & 272 & 273 \\
600 & 273 & 241 & 246 & 250 & 253 & 252 \\
800 & 300 & 208 & 211 & 215 & 218 & 222 \\
\hline
\end{tabular}

Table 8 Ignition delay of fuel combustion in comparison to TDC.

\begin{tabular}{|c|c|c|c|c|c|c|}
\hline \multirow{2}{*}{ No. } & \multirow{2}{*}{$\begin{array}{l}\text { Load } \\
(\mathrm{kW})\end{array}$} & \multicolumn{5}{|c|}{ A moment of fuel combustion in comparison to TDC (s) } \\
\hline & & DO & PO5 & PO10 & PO15 & PO20 \\
\hline 1 & 200 & 0.0017 & 0.0017 & 0.0017 & 0.0017 & 0.0008 \\
\hline 2 & 400 & 0.0021 & 0.0016 & 0.0016 & 0.0016 & 0.0012 \\
\hline
\end{tabular}

Table 9 Content of $\mathrm{NO}_{\mathrm{x}}$ in exhaust gas.

\begin{tabular}{llllllllll}
\hline \multicolumn{10}{c}{ Content $\mathrm{NO}_{\mathrm{x}}$ on engine esmissions } \\
\hline & $\mathrm{DO}$ & \multicolumn{10}{c}{$\mathrm{PO} 5$} & \multicolumn{3}{c}{$\mathrm{PO} 10$} & \multicolumn{2}{c}{$\mathrm{PO} 15$} & \multicolumn{2}{c}{$\mathrm{PO} 20$} \\
\hline $\mathrm{Ppm}$ & $\mathrm{g} / \mathrm{kWh}$ & $\mathrm{ppm}$ & $\mathrm{g} / \mathrm{kWh}$ & $\mathrm{ppm}$ & $\mathrm{g} / \mathrm{kWh}$ & $\mathrm{ppm}$ & $\mathrm{g} / \mathrm{kWh}$ & $\mathrm{ppm}$ & $\mathrm{g} / \mathrm{kWh}$ \\
940,45 & 19.4 & 844.51 & 15.7 & 894.06 & 18.6 & 873.99 & 16.6 & 576.62 & 13.6 \\
\hline
\end{tabular}

blended fuel shows that: at lower loads (200 kW), the start of combustion of blended fuel PO5, PO10 and PO15 quite coincides with the start of combustion of DO, but PO20 starts of burn slower than DO two times (0.0008 s); while at higher load (400 kW), the start of combustion of the blended fuels is not the same as the before. They started to burn with the higher separation and it is clear that the start of combustion of the blended fuels: PO5, PO10 and PO15 no longer coincides with the DO, which is about 1.31 times slower, and PO20 is 1.75 times slower than DO.
The impact on the environment is also evaluated by measurements and analysis of toxic substances such as $\mathrm{NO}_{\mathrm{x}}, \mathrm{CO}, \mathrm{CO} 2$, Hydrocarbon. But now, for the marine diesel engine, $\mathrm{NO}_{\mathrm{x}}$ must be seriously taken into consideration in accordance to the Annex VI of MARPOL 73/78 Convention. According to Annex VI regulations, the limit emissions permitted for diesel engine 6LU32 is 14.19 (g/kW.h). The measured results showed that $\mathrm{NO}_{\mathrm{x}}$ concentrations in exhaust gas when using blended fuels is lower than that of DO fuel, especially with blended fuel with $20 \%$ amount of palm oil (PO20), $\mathrm{NO}_{\mathrm{x}}$ content in the exhaust gas is 
only 13.6 (g/kW.h), fully meet the requirements of MARPOL 73/78 Convention.

Results of test carried out on board of vessel "Hoa Nam” Hoa Nam is dry cargo vessel with particulars as follows: length overall: $9 \mathrm{~mm}$, breadth: $18 \mathrm{~m}$, depth: $4.8 \mathrm{~m}$, gross tonage: $5,470 \mathrm{GT}$, sea going speed: 10.5 knots. Main diesel engine: 6LF-46 (Hanshin-Japan) with power: 3,900 HP, revolution: 245 (rpm). The experiment was made on board of Hoa Nam vessel as show in Fig. 8.
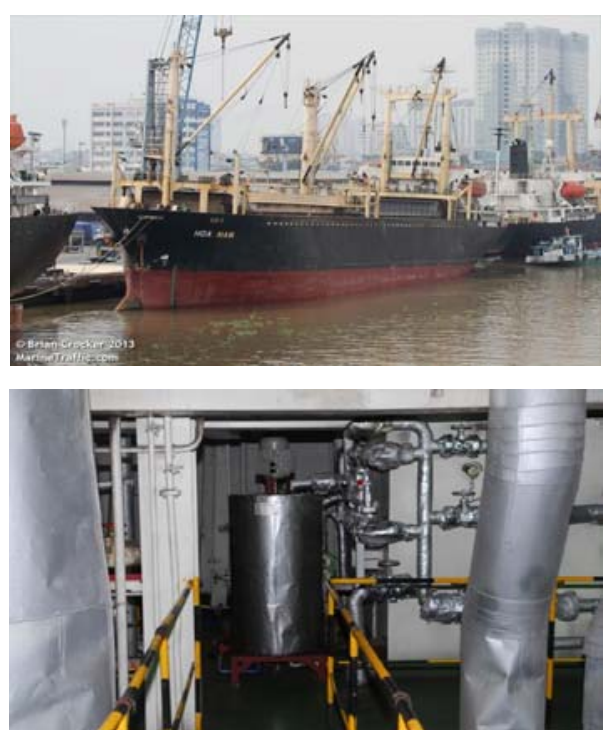

Fig. 8 Experiment for blended fuels in "Hoa Nam” vessel.
The experiment results are shown in Tables 10-12. Due to the limitations of the measuring equipment, the parameters measured during the experiment are a little different in comparison with that in the laboratory.

After analysing the results measured on board ship such as maximum combustion pressure, fuel consumption rate and the concentration of harmful gases in the exhaust of the engine, the are some following comments:

Basically, the maximum combustion pressures in
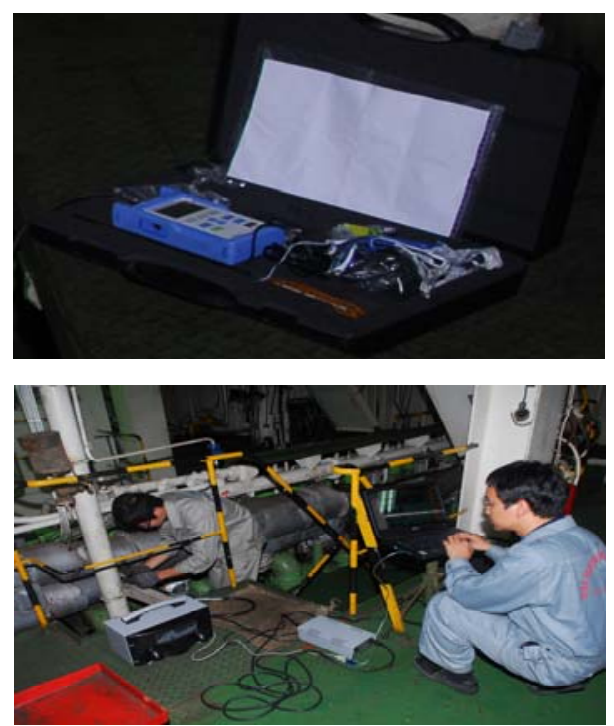

Table 10 Fuel consumption for different fuels.

\begin{tabular}{llll}
\hline Blended fuel & Consumption (l/15minutes) & Consumption (g/kW.h) & Different (\%) \\
\hline DO & 60 & 269 & - \\
PO5 & 61 & 274 & $+1.85 \%$ \\
PO10 & 63 & 277 & $+2.97 \%$ \\
PO20 & 63.5 & 278.5 & $+3.53 \%$ \\
\hline
\end{tabular}

Table 11 The maximum combustion pressure when using different fuels.

\begin{tabular}{lllll}
\hline & Type of fuel oil & & & \\
\cline { 2 - 5 } & DO & PO5 & PO10 & PO20 \\
\hline Burning pressure Pz (kG/cm2) & 40 & 40.5 & 42 & 41 \\
Different (\%) & - & +1.25 & +5 & +2 \\
\hline
\end{tabular}

Table 12 Esmission levels for different types of fuel.

\begin{tabular}{lll}
\hline Type of fuel & Light absorption coefficient- $k\left(\mathrm{~m}^{-1}\right)$ & Light transmission OPAC (\%) \\
\hline DO & 0.77 & 79.1 \\
PO5 & 0.74 & 79.8 \\
PO10 & 0.94 & 75.1 \\
PO20 & 0.97 & 74.9 \\
\hline
\end{tabular}


the cylinders of the engine when operating at rate of 1,130 kW for DO and blended fuels are very similar. Running with DO, the diesel engine generated maximum pressure of $40 \mathrm{~kg} / \mathrm{cm}^{2}$, while for PO5, maximum pressure reached $40.5 \mathrm{~kg} / \mathrm{cm}^{2}$, up $1.25 \%$. While the engine is using PO10, the maximum combustion pressure is $42 \mathrm{~kg} / \mathrm{cm}^{2}$, increasing $5 \%$ and also increasing by $2 \%$ for PO20;

The fuel consumption is equivalent when the diesel engine used PO5 and DO; while the diesel engine used PO10 and PO20, the fuel consumption rate increased by $2.9 \%$ and $3.1 \%$, respectively;

The emissions of exhaust gas of the diesel engine which used blended fuels: PO5, PO10 and PO20, are more positive than that of the diesel engine using DO. Because, the combustion of blended fuel took better place in cylinders due to the existence of oxygen content in the structure of biofuel;

So, it can be summarised that there is no negative expression in combustion chambers when the diesel engine used the mixed fuel (PO5 to PO20). The results of experiment also confirm better quality of exhaust gas discharged into the environment when the diesel engine used blended fuels in comparison with that when the same engine used DO. Thus also create one of the solutions to allow existing diesel engines equipped on board ships to achieve the emission quality standard required by IMO. Hence, it is perfectly possible to use blended palm oil replacing the traditional DO for marine application.

\section{Conclusions}

There are some differences between pure palm oil and DO: the density of pure palm oil is $8.99 \%$ higher than that of DO; the kinematic viscosity and the flash point of pure palm oil at $40{ }^{\circ} \mathrm{C}$ are 13.4 times, 3.1 times higher than that of $\mathrm{DO}$, respectively; the freezing point of pure palm oil is $16{ }^{\circ} \mathrm{C}$ while of DO is $-6{ }^{\circ} \mathrm{C}$; the calorific value of pure palm oil is $3.95 \%$ lower than that of DO. However, the mixture of pure palm oil and DO has very similar physical and chemical properties to DO.

Marine diesel engines usually have a large capacity, an average and low revolution, so they require fuels with not so high quality, such as DO and MDO. Because, marine diesel engines are equipped with remarkably complete gas exchange system and comprehensive fuel supply system, therefore, it is very capable for them to use the blended palm oil as well as other biodiesel as alternative fuel.

When studying on characteristics of propulsion plant of inland waterway vessels, it is found that for the purpose of using the blended palm oil for the marine diesel engines, there just needs to renovate the fuel supply system by equipping on-line mixing equipment (Fig. 4). The automatic system to control the on-line fuel mixer is designed and manufactured based on PLC (programmable logic controller) technology, through which operators can easily operate and control the working of the device. Performing multiple tests, the on-line fuel mixer has the following characteristics: it can make batch mixing or continuous mixing (on-line); acceptable mixing time and temperature are 10 minutes and $40{ }^{\circ} \mathrm{C}$ respectively; the volume of the mixing device is determined by the fuel consumption rate of a diesel engine and optimum stirring speed is $60 \mathrm{rpm}$. It can confirm that the on-line fuel mixer is very reliable and easy to operate. The equipment was checked and certified by Vietnam Register.

The experiment has been done at the laboratory as well as onboard ship showed that the fuel mixture DO is fully usable to replace traditional fuels DO for marine diesel engines installed on board ships of inland waterway fleet in Vietnam. Using blended palm oil from PO5 to PO15, the technical specifications of diesel engines have not changed much since the engines using DO, however, significantly improved the quality of harmful emissions.

\section{Referenes}

[1] Sanford, D., White, J. M., Shah, P. S., Wee, C., 


\section{A Study on Conversion of Marine Diesel Engines Using Blended Palm Oil for Inland Waterway Vessels in Vietnam}

Valverde M. A., and Meier, G. R. 2009. Feedstock and Biodiesel Characteristics Report. Renewable Energy Group, USA.

[2] Kido, H. 2010. "The Basis of Diesel Plant Performance Calculation.” Ph.D thesis, University of California.

[3] IMO, SOLAS (Convention on the Safety of Life at Sea) 74, Published on 2000.

[4] Piotrowski, I., and Witkowski, K. 2003. Okretowe Silniki Spalinowe, Trademar, Gdynia-Poland.

[5] Challen, B., and Baranescu, R. 1999. Diesel Engine Reference Book. Oxford: Butterworth-Heinemann.

[6] Klein, M. 2004. A Specific Heat Ratio Model and Compression Ratio Estimation. Sweden: Linkoping.

[7] Kuiken, K. 2008. Diesel Engines for Ship Propulsion and Power Plants. The Netherland: Onmen.

[8] Boyd, M. 2007. The Auto-ignition Properties of Biodiesel Fuels. Australia: The University of Adellaide.

[9] Tat, M. E., and Van Gerpen, J. H. 2003. Measurement of Biodiesel Speed of Sound and Its Impact on Injection Timing. Final Report, Department of Mechanical Engineering, Iowa State University, USA.

[10] IMO, 2008. MARPOL (Maritime Agreement Regarding Oil Pollution) 73/78, Published on 2008.
[11] Terry, B., McCormick, R., and Natarajan, M. 2006. Impact of Biodiesel Blends on Fuel System Component Durability. SAE Technical Paper 2006-01-3279, doi:10.4271/2006-01-3279.

[12] Ohkawa, K., Hirata, Y., Inoue, Y. 2008. "Flow and Mixing Characteristics of $\sigma$-type Plate Static Mixer with Splitting and Inverse Recombination.” Chemical Engineering Research and Design 86 (12): 1447-53.

[13] Quang, N. P. 2003. Matlab \& Simulink NXB KHKT. 2003.

[14] Galaktionov, O. S., Anderson, P. D., Peters, G. W., and Meijer, H. E. 2003. "Analysis and Optimization of Kinetics Statics Mixers.” Int. Polym. Process 18 (2): 138-150.

[15] Office of World Energy Council, 2010. Biofuels: Policies, Standards and Technologies. World Energy Council.

[16] Hart Energy Consulting, 2007. Establishment of the Guidelines for the Development of Biodiesel Standards in the APEC Region. Hart Energy Publishing.

[17] High Performance Fluid Mixing; Chempro Gujarat India, August 2011. 